\title{
Water footprint in family farming
}

\author{
Pegada hídrica na agricultura familiar \\ Huella hidrica em la agricultura familiar
}

Received: 05/05/2021 | Reviewed: 05/10/2021 | Accept: 05/12/2021 | Published: 05/29/2021

\author{
Ana Luiza Grateki Barbosa \\ ORCID: https://orcid.org/0000-0002-8771-8167 \\ Universidade Federal dos Vales do Jequitinhonha e Mucuri, Brazil \\ E-mail: al_grqateki@hotmail.com \\ Daniel Brasil Ferreira Pinto \\ ORCID: https://orcid.org/0000-002-6968-8435 \\ Universidade Federal dos Vales do Jequitinhonha e Mucuri, Brazil \\ E-mail: daniel.brasil@ufvjm.edu.br \\ Rafael Alvarenga Almeida \\ ORCID: https://orcid.org/0000-0002-3828-7305 \\ Universidade Federal dos Vales do Jequitinhonha e Mucuri, Brazil \\ E-mail: Rafael.almeida@ufvjm.edu.br
}

\begin{abstract}
Currently, the management of water resources has gained greater visibility and has become indispensable, with the need for different methodologies which consider all water used and incorporated in the processes and products. In this way, the water footprint concept has been introduced to calculate the appropriation of fresh water on the part of the humankind. Thus, the objective of this work was to determine the water footprint in some sectors of family farming in the municipality of Teófilo Otoni - MG, analyzing the agricultural production of crops cultivated exclusively by the sector in 2017 in Teófilo Otoni. The cultivation of pumpkin, banana, chayote, beans, cassava, Maize, peppers, okra, cabbage, and tangerine were studied. Thus, the total water footprint for the year 2017 was $13,996,735.05 \mathrm{~m}^{3} \cdot \mathrm{t}^{-1}$, in which the green water footprint represents $86 \%$, the blue water footprint represents $12.5 \%$ and the gray water footprint equals $1.5 \%$. The family farming sector of Teófilo Otoni demands an average of 196.73 liters for a production of R\$ 1.00 .
\end{abstract}

Keywords: Water management; Virtual water; Water crisis.

\section{Resumo}

Atualmente a gestão dos recursos hídricos tem ganhado maior visibilidade e se tornado indispensável, com a necessidade de metodologias diversas as quais consideram toda água utilizada e incorporada nos processos e produtos. Deste modo o conceito de pegada hídrica tem sido introduzido para calcular a apropriação da água doce por parte da humanidade. Assim, objetivou-se com este trabalho a determinação da pegada hídrica em alguns setores da agricultura familiar no município de Teófilo Otoni - MG, analisando a produção agrícola de culturas cultivadas exclusivamente pelo setor no ano de 2017 em Teófilo Otoni. Foram estudados o cultivo de abóbora, banana, chuchu, feijão, mandioca, milho verde, pimentão, quiabo, repolho e tangerina. Assim a pegada hídrica total para o ano de 2017 foi de 13.996.735, $05 \mathrm{~m}^{3} . \mathrm{t}^{-1}$, na qual a pegada hídrica verde representa $86 \%$, a pegada hídrica azul representa $12,5 \%$ e a pegada hídrica cinza equivale a 1,5\%. O setor de agricultura familiar de Teófilo Otoni demanda em média 196,73 litros para produção de $\mathrm{R} \$ 1,00$.

Palavras-chave: Gestão hídrica; Água virtual; Crise hídrica.

\section{Resumen}

Actualmente la gestión de los recursos hídricos ha ganado mayor visibilidad y se ha vuelto indispensable, con la necesidad de diferentes metodologías que consideren toda el agua utilizada e incorporada en procesos y productos. De esta forma, se ha introducido el concepto de huella hídrica para calcular la apropiación de agua dulce por parte de la humanidad. Así, este trabajo tuvo como objetivo determinar la huella hídrica en algunos sectores de la agricultura familiar en el municipio de Teófilo Otoni - MG, analizando la producción agrícola de cultivos cultivados exclusivamente por el sector en 2017 en Teófilo Otoni. Se estudió el cultivo de calabaza, plátano, chayote, frijol, mandioca, maíz verde, pimiento, quimbombó, repollo y mandarina. Entonces, la huella hídrica total para el año 2017 fue 13.996.735, $05 \mathrm{~m}^{3} \cdot \mathrm{t}^{-1}$, en la que la huella hídrica verde representa el $86 \%$, la huella hídrica azul representa el $12,5 \%$ y la huella hídrica gris es igual al 1,5\%. El sector de la agricultura familiar de Teófilo Otoni demanda un promedio de 196,73 litros para una producción de R \$1,00.

Palabras clave: Gestión del agua; Agua virtual; Crisis de agua. 


\section{Introduction}

Water is an indispensable natural resource for all living beings; however, it is not found equally available on the planet, often in conditions that are unable to meet basic needs in some locations and in others it can be found abundantly. In addition to this disparity, freshwater suffers anthropic impacts, due to the intense industrialization that generates a high production of effluents and residues that contaminate the environment causing damage to the quality and quantity of water resources.

Techniques are needed to manage this vitally important resource so that the entire population and all economic activities have access to this asset. The control of water resources in Brazil is based on legislation, providing management tools derived from policies that define the participation of institutions, entities, and bodies for congruent management.

Economic activities and the amount of water consumption in a region depend directly on the availability and reality of water resources, which consequently interferes with the quality of life and the economic development of the population (Nogueira, 2010). Despite their relevance, these activities cause damage that is difficult to minimize, and the impacts caused are the result of archaic models of the use of natural resources and poor management (UN, 2015).

The most significant activities in the country, agriculture is of great economic importance. In recent years, Brazil for presenting large tracts of agricultural land and experienced and accessible labor, has stood out as one of the largest exporters of agricultural commodities and livestock products in the world, with this the consumption of water for crop irrigation processes and animals watering trough in addition to generating nutrient-rich effluents, which can cause eutrophication of water bodies, there is also a drastic increase in the degradation of large areas for food production (MAPA, 2016).

As the agribusiness sector is mostly exported, it is up to the domestic market in Brazil, which refers to the demand of the Brazilian population, to be served by the family farming sector, which has small properties and limited environmental resources. In this way, the relationship between water and agricultural production must be addressed in an efficient manner, so that the real impacts caused by the consumption of water and the production of effluents in all stages of production are known.

An effective concept is the water footprint methodology that reveals the circumstances of direct and indirect uses of water resources and their sources of capture, and also exposes the water impacts caused. This method is an important tool for water management, it is an indicator of use and processes that most demand water resources in certain areas and products. Thus, the water footprint allows knowledge of water consumption, pollution and local impact in a broader way for producers and consumers (Hoekstra et al., 2011). Given the above, the objective of the research was to make an analysis of the water footprint and its application in the family farming sector in the municipality of Teófilo Otoni- MG.

\section{Methodology}

\section{Study area}

The municipality of Teófilo Otoni, Figure 1, is located in the northeastern region of Minas Gerais, considered the macro-regional center of Mucuri Valey, has a territorial area of 3,242,270 $\mathrm{km}^{2}$ and a population of 141,046 . The municipality is comprised between the coordinates $17^{\circ} 51^{\prime} 27^{\prime \prime}$ South and $41^{\circ} 30$ ' $19^{\prime \prime}$ West and has a minimum altitude of 182 meters and a maximum altitude of 1049 meters (IBGE, 2016). The climate is characterized as semi-humid hot tropical Aw type according to the Köppen classification (Kottek et al., 2006). 
Figure 1. Location of the municipality of Teófilo Otoni in the state of Minas Gerais, Brazil.

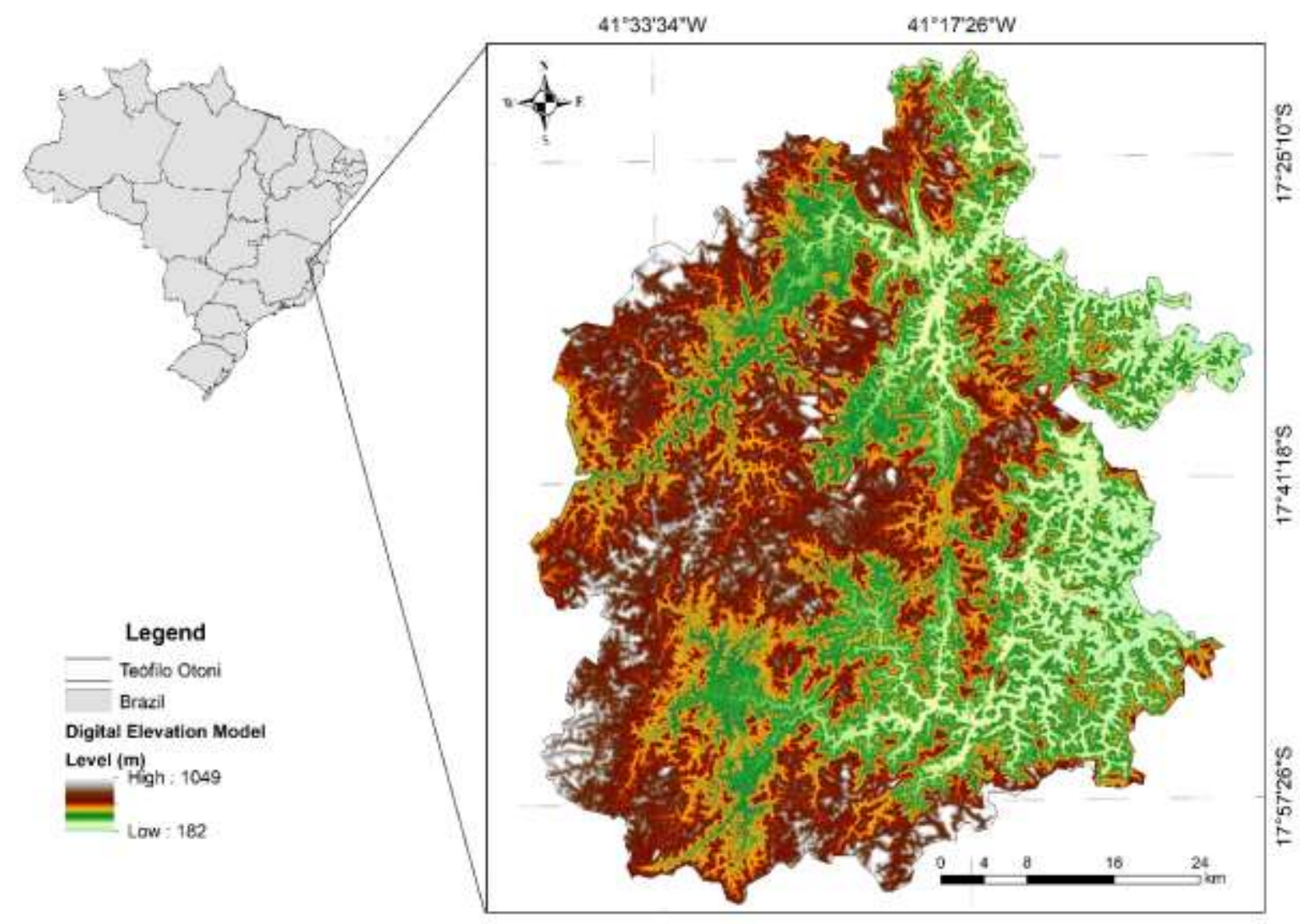

Source: Authors.

The municipality's hydrography consists mainly of the Mucuri river and the Todos os Santos river, which flows within the urban area and is responsible for the public supply of the population. The region's economy is based on agricultural practices, thus agricultural production is composed of products such as: coffee, cassava, vegetables, cereals, fruits and vegetables and eucalyptus production. However, agricultural production has been decreasing in proportion to the increase in livestock production. (Godinho et al, 2008).

\section{Land use and occupation}

In order to identify the types of land use and occupation in Teófilo Otoni and the areas that each class occupy, a study was made of the use and occupation of land for the municipality. Images from the RapidEye satellite with a spatial resolution of 5 meters were used, provided and pre-processed by the Northeast Regional Institute of Forests (IEF). For the mosaic, nine scenes were used, dated between July 27, 2012 and November 21, 2012.

The study considered 6 classes of land use and occupation included in: Agriculture, Water and Rock, Urban Area, Forest, Pasture and Exposed Soil. The classification was made following the maximum likelihood analysis method (MAXVER) using ArcGis software version 10.5.1 (Mccoy, 2005).

In order to improve the final product of the mapping of land use and occupation, filters were used for image processing after the supervised classification using the commands "Majority Filter", "Boundary Clean", "Region Group", "Set Null" and "Nibble". This processing has the function of modifying geometric details in the study, generating a cleaner image without isolated pixels (Almeida, 2016). 
To validate the study of land use and occupation, the Kappa Index method was used, which is based on a confusion matrix that compares samples referring to field reality and samples from the mapping. The methodology applied to verify the accuracy of the final product was the one described by Almeida et al. (2018).

\section{Data collection}

\section{Cultivation data}

In the study of the water footprint in the family farming sector of Teófilo Otoni, the crops produced exclusively by the sector in the municipality were analyzed. The data regarding the type and production of the crop were made available by the Technical Assistance and Rural Extension Company (Emater) of the Teófilo Otoni region. The information was related to the 2017 agricultural harvest, obtained through the municipality's Synthetic Report.

The evaluated Crop, the aspects of cultivation and the cultivation coefficient of each culture comprising the initial stage (Kci), the mid-season stage $(\mathrm{Kcm})$ and the final stage stage (Kcf) of development of the culture are shown in Table 1.

Table 1. Aspects of cultivation of crops produced by family farming in the municipality of Teófilo Otoni.

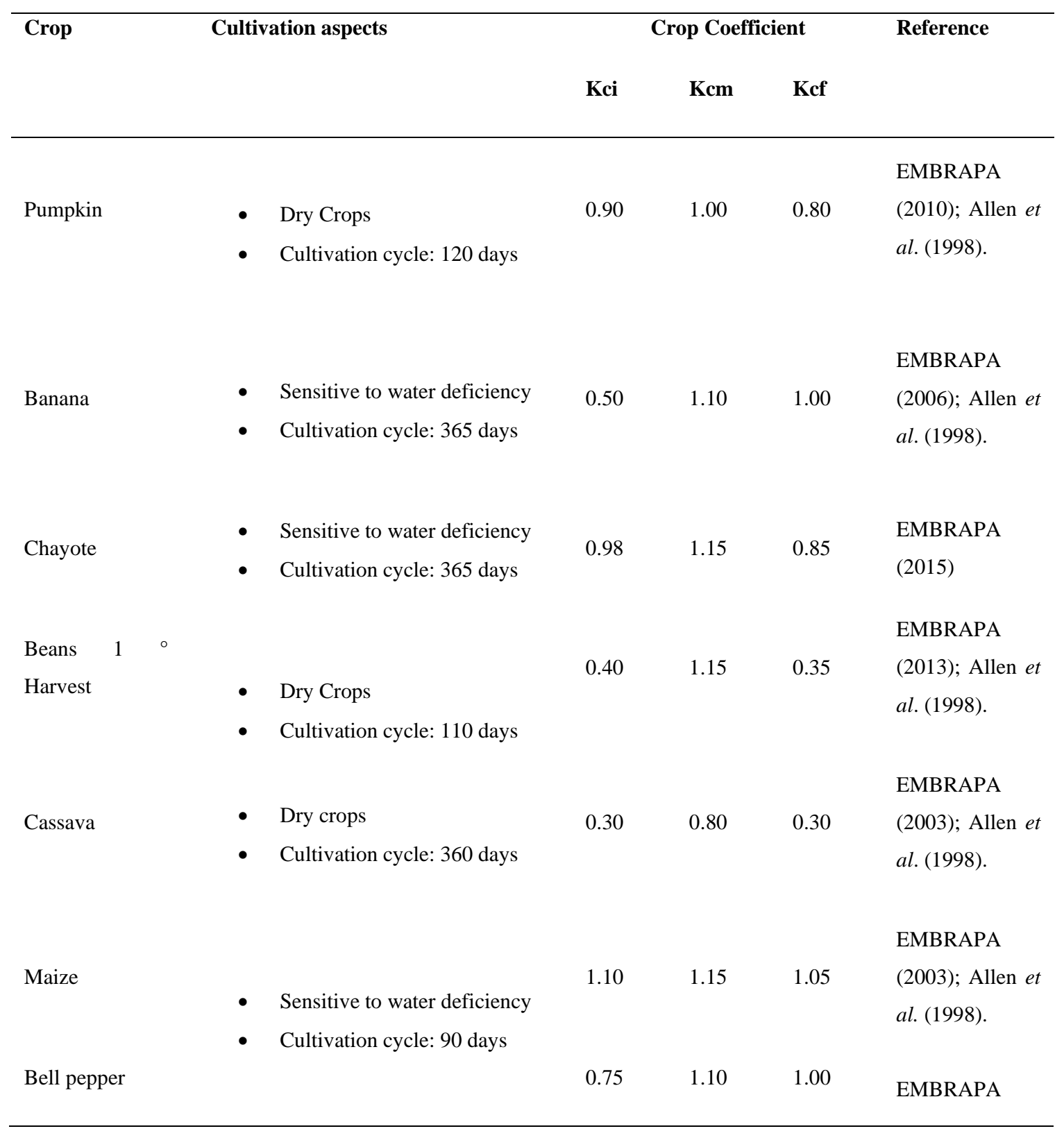




\begin{tabular}{|c|c|c|c|c|c|}
\hline & - $\quad$ Sensitive to water deficiency & & & & (2012) \\
\hline Okra & $\begin{array}{l}\text { - } \\
\text { - } \quad \text { Cultivation cycle: } 180 \text { days }\end{array}$ & 0.65 & 0.68 & 0.79 & $\begin{array}{l}\text { EMATER } \\
\text { (1982); PAES et } \\
\text { al (2012). }\end{array}$ \\
\hline Cabbage & $\begin{array}{l}\text { - } \\
\text { - } \quad \text { Cultivation cycle: } 165 \text { days }\end{array}$ & 1.00 & 1.05 & 0.95 & $\begin{array}{l}\text { EMBRAPA } \\
\text { (1994); Allen et } \\
\text { al. (1998). }\end{array}$ \\
\hline Tangerine & $\begin{array}{l}\text { - } \\
\text { - } \quad \text { Cultivation cycle: } 365 \text { days }\end{array}$ & 0.75 & 0.65 & 0.70 & $\begin{array}{l}\text { EMBRAPA } \\
\text { (2003). }\end{array}$ \\
\hline
\end{tabular}

Climate data. Source: Authors.

The data of monthly averages of the information referring to rainfall, relative air humidity, wind speed, maximum and minimum temperatures for the blue and green water footprint calculations were obtained through the automatic weather station of Teófilo Otoni (A527) provided by the National Institute of Meteorology (INMET) belonging to the period of 2007 to 2017.

The analysis of climatic data to obtain the Reference Evapotranspiration (ET0) and Effective Precipitation (Peff), the software CROPWAT version 8.0, made available by the Food and Agriculture Organization of the United Nations (FAO), was used. Thus, the calculation for obtaining the ET0 was based on the Penman-Monteith method (Allen et al., 1998). In the absence of data related to the monthly average of insolation, the monthly average values available in the Solarimetric Atlas of Minas Gerais were used, that used information from 1960 to 2012 from INMET, CEMIG, CPTEC database and the Solarimetric Atlas of Brazil (CEMIG, 2012).

Following the recommendations made by Hoesktra et al. (2011) to obtain effective precipitation, which consists of counting the precipitated water that is retained in the soil and is potentially available for the development of the crop, was estimated from the monthly average using the method developed by the United States Department of Agriculture's Soil Conservation Service (USDA, 1994).

The averages of the climatic data used to calculate the reference evapotranspiration (ET0) and the effective precipitation (Peff) applied in the CROPWAT 8.0 software, covering the period from 2007 to 2017 are shown in Table 2 (FAO, 2010). 
Table 2. Climatic data for the municipality of Teófilo Otoni from 2007 to 2017.

\begin{tabular}{lllllcc}
\hline Month & $\begin{array}{l}\text { Min } \\
\left({ }^{\circ} \mathbf{C}\right)\end{array}$ & $\begin{array}{l}\text { Máx } \\
\left({ }^{\circ} \mathbf{C}\right)\end{array}$ & $\begin{array}{l}\text { Humidity } \\
(\boldsymbol{\%})\end{array}$ & $\begin{array}{l}\text { Speed } \\
\left(\mathbf{m} . \mathbf{s}^{\mathbf{- 1}}\right)\end{array}$ & $\begin{array}{c}\text { Insolation } \\
(\text { hours })\end{array}$ & $\begin{array}{c}\text { Precipitation } \\
(\mathbf{m m})\end{array}$ \\
\hline January & 20.9 & 29.7 & 73.0 & 2.0 & 8.5 & 100.6 \\
February & 21.3 & 30.3 & 70.5 & 2.0 & 8.5 & 63.5 \\
March & 21.5 & 30.4 & 74.0 & 1.5 & 7.5 & 131.5 \\
April & 20.4 & 28.5 & 76.9 & 1.2 & 6.5 & 82.1 \\
May & 18.3 & 26.5 & 77.0 & 1.1 & 6.0 & 32.0 \\
June & 17.3 & 25.7 & 75.3 & 1.1 & 6.0 & 20.4 \\
July & 16.6 & 25.7 & 73.0 & 1.3 & 5.5 & 22.4 \\
August & 17.0 & 26.5 & 69.0 & 1.7 & 7.0 & 24.3 \\
September & 18.2 & 27.8 & 66.7 & 2.1 & 5.5 & 18.4 \\
October & 19.8 & 24.0 & 68.0 & 2.3 & 4.5 & 93.8 \\
November & 20.1 & 28.1 & 74.9 & 1.9 & 4.5 & 258.2 \\
December & 21.3 & 28.8 & 75.0 & 1.8 & 5.0 & 210.0 \\
\hline
\end{tabular}

Source: Adapted IMNET (2018); CEMIG (2012).

\section{Water footprint in family farming}

\section{Green water footprint (PHgreen)}

The green water footprint (PHgreen) is water from precipitation that is retained in the soil or temporarily on its surface and vegetation, it does not drain or supply groundwater. That portion is usually evaporated or is transpired by plants, in this way it is used in the production process of crops, it has relevant importance in agricultural and forest products.

For the calculation of the green water footprint of this study, all precipitation used for the production of crops grown in the municipality of Teófilo Otoni was considered. Crop that are not sensitive to water deficiency and are cultivated by the rainfed method have precipitation as the only water source and for such Crop only the green and gray water footprint was calculated. Equation 1 comprises the ratio between water demand for crop productivity, the productivity data for each crop was obtained by Emater's report. The calculation for rainwater consumption for agricultural production follows the method of Hoekstra et al. (2011).

$P H_{\text {Green }}=\frac{\text { DHC Green }}{Y}$

were,

$\mathrm{DHC}_{\text {green }}=\mathrm{It}$ is the water demand of the culture.

$\mathrm{Y}=$ Productivity. 


\section{Blue water footprint (PHBlue)}

The blue water footprint (PHBlue) concept defines the water resources that are available on the surface and in underground reserves, refers to water that is consumed in a certain period of time and that does not return immediately to the basin after use, characterizing losses.

For the calculation of the blue water footprint, the types of crops that need to be irrigated on days when effective precipitation is not able to supply vegetative needs were identified. Described in Table 1 in their cultivation aspects, they are sensitive to water deficiency, as follows: banana, chayote, maize, bell pepper, cabbage, and tangerine. The blue water footprint was obtained with the aid of Equation 2 for each culture. The total blue water footprint is the sum of the blue water footprints of each culture (Hoekstra et al., 2011).

PH $H_{\text {Blue }}=\frac{\text { DHC Blue }}{Y}$

were,

$\mathrm{DHC}_{\mathrm{Blue}}=\mathrm{It}$ is the water demand of the culture.

$\mathrm{Y}=$ Productivity.

To obtain the water demand of the crop (DHC blue) Equation 3 proposed by Hoekstra et al. (2011).

DHCblue $=10 \sum_{d=1}^{p d c}$ ET blue

For the calculation of the Water Demand for Culture (blue DHC) it was estimated the need for irrigation of the crop in which the effective precipitation was not able to supply shortage of the crop. To obtain the total evaporation of the culture, Equation 4 was applied.

ET blue $=\max (0$, ETc - Peff $)$

Thus, when the effective precipitation is greater than the evapotranspiration of the crop, the need for irrigation is equal to 0 . The total evapotranspiration for the calculation of the blue water footprint was obtained by adding all the blue ET over the entire growing period of the crop.

\section{Gray water footprint (PHGray)}

The gray water footprint (PHGray) explains the amount of water needed to incorporate the entire pollutant load associated with the process steps so that the receiving water body remains with natural concentrations and acceptable environmental standards.

In this analysis, the pollution generated in agricultural production, from the application of fertilizers in crops, was considered. Nitrogen and phosphorus were studied because they are active ingredients of the most widely used fertilizers according to data collected from producers and traders in the region and because they are an aggravating factor in the eutrophication process of water bodies (Palhares, 2011). In calculating the gray water footprint, only the nutrient that has the largest gray water footprint for each culture was considered according to guidelines made by Hoekstra et al. (2011). 
The gray water footprint in agriculture considered the entire effluent load generated in agricultural production. Therefore, it was calculated in relation to diffuse pollution from fertilizers applied to crops (Hoeskstra et al., 2011).

$P H_{\text {gray }}=\frac{\propto, \text { Apl }}{(\text { Cmax }- \text { Cnat }) . Y}$

were,

$\alpha=$ Leaching factor of the nutrient.

$\mathrm{Apl}=$ Amount applied of the nutrient.

$\mathrm{C}_{\max }=$ Maximum concentration acceptable in the legislation .

$\mathrm{C}_{\mathrm{nat}}=$ Concentration of the pollutant in natural conditions.

$\mathrm{Y}=$ Productivity.

The nitrogen leaching factor was $10 \%$ specified by Hoekstra et al. (2011). The main river in the municipality is classified as class II, so the maximum allowed concentration for nitrogen was $10 \mathrm{mg} . \mathrm{I}^{-1}$ obtained in resolution 357 of CONAMA (2005). The natural concentration of the receiving water body was considered zero, for substances of human origin that do not naturally occur or that their concentrations are exceptionally low (Hoeskstra et al., 2011).

For the phosphorus, the carrying factor indicated by Piovesan (2006) was adopted, assigning the value of $1 \%$, following the provisions of CONAMA in resolution 357 of 2005 for class II rivers, the maximum permitted phosphorus concentration is $0.1 \mathrm{mg} \cdot \mathrm{l}^{-1}$. For natural phosphorus concentration following the FUNASA report (2014) it is $0.03 \mathrm{mg} \cdot \mathrm{l}^{-1}$.

\section{Economic water productivity}

To assess how much water is used to produce $\mathrm{R} \$ 1.00$ by the family farming sector in the municipality of Teófilo Otoni, the average price used by producers for the sale of crops was considered. The survey was carried out at the main free markets located in the city, as they are the main means of marketing products originating from family farming. The sale value of each crop was researched in three producers to obtain the average sale value of each kilo.

\section{Results and Discussion}

\section{Land use and occupation}

Figure 2 shows the main classes of land use and occupation in the municipality of Teófilo Otoni. The accuracy of the mapping carried out by calculating the Kappa index was 0.77 and the quality was defined as very good. According to Silva et al. (2017), who evaluated the soil cover in the sub-basin Córrego dos Bois-MG, define that the images of the RapidEye satellite have high levels of detail, which make it possible to produce mappings with a high index of reliability. 
Figure 2. Map of land use and occupation in the municipality of Teófilo Otoni - MG.

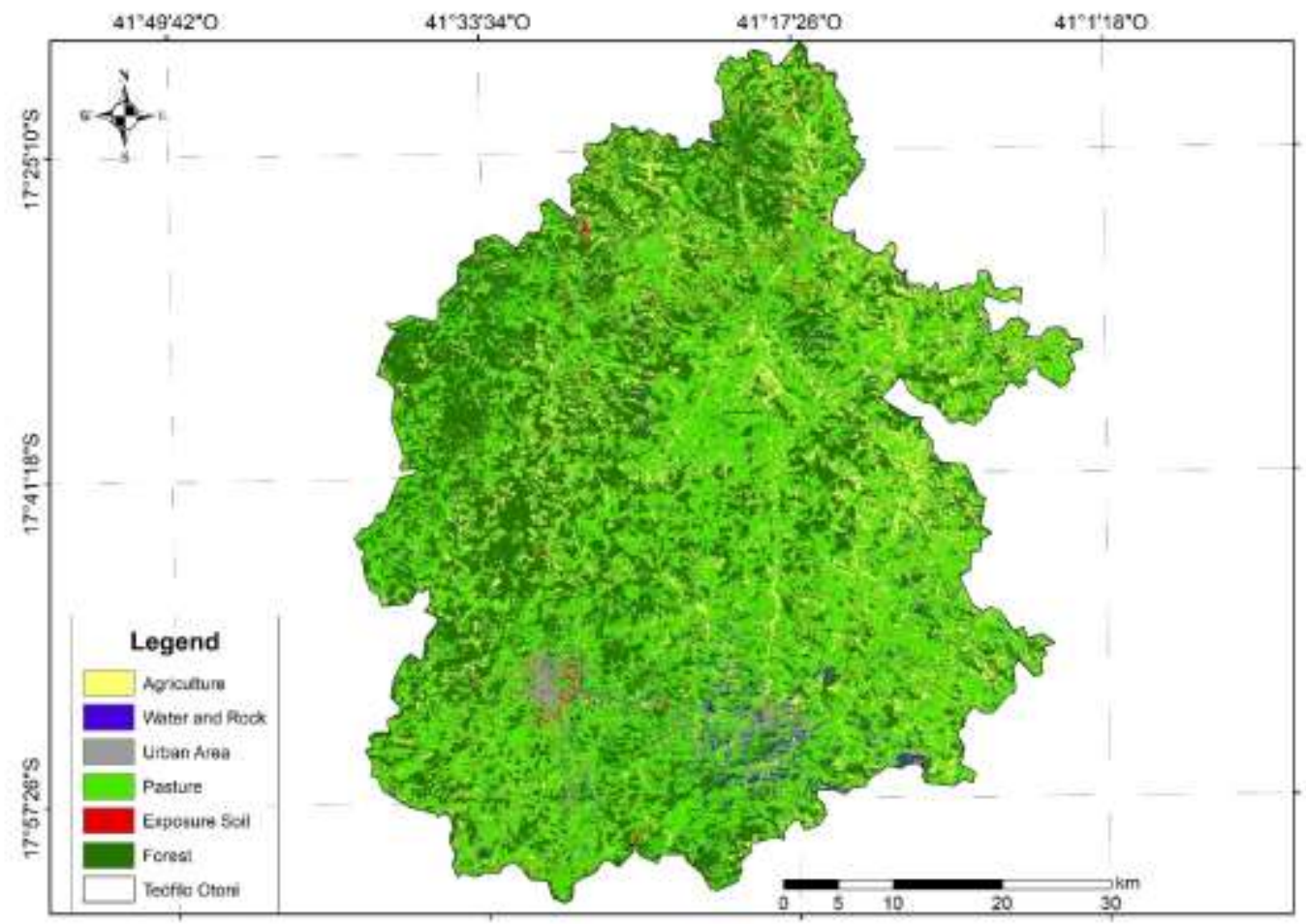

Source: Authors.

The highest occurrence of the Pasture class was expected, given that the region's economy is based on livestock activities. (Godinho et al., 2008). Similar results were obtained in studies by Nascimento \& Fernandes (2017) with pasture as the predominant class in the small hydrographic basin of the Amazon in the municipality of Capitão Poço - PA, which presented livestock activity as one of the main sources of income in the region.

\section{Reference evapotranspiration and effective precipitation}

After applying the Cropwat software, the data obtained for the calculation of ET0 and Peff for the municipality of Teófilo Otoni are presented in Table 3.

Table 3. ET0 and Peff values for Teófilo Otoni - MG

\begin{tabular}{lll}
\hline Month & $\mathbf{E t}_{\mathbf{0}}\left(\mathbf{m m . d a y}{ }^{-1}\right)$ & Peff $(\mathbf{m m})$ \\
\hline January & 5.20 & 84.4 \\
February & 5.22 & 48.0 \\
March & 4.52 & 90.9 \\
April & 3.57 & 52.1 \\
May & 2.84 & 11.4 \\
June & 2.55 & 41.6 \\
July & 2.64 & 26.4 \\
August & 3.48 & 26.6 \\
September & 4.02 & 1.4 \\
October & 3.89 & 112.2 \\
November & 3.92 & 114.3 \\
December & 4.26 & 135.5 \\
\hline Average & 3.84 & - \\
\hline
\end{tabular}


Source: Authors.

The average ET0 value found was $3.84 \mathrm{~mm} \cdot \mathrm{day}^{-1}$, which made it possible to obtain the water demand of the crop from precipitation for the application of the green water footprint for the municipality. Accordingly, a close value was found in studies by Carvalho et al. (2015) who estimated ET0 of $3.96 \mathrm{~mm}_{\text {.day }}{ }^{-1}$ for Teófilo Otoni by the method recommended by FAO.

The analysis of the blue water footprint considered the average ET0 and the Peff belonging to each month to assess the water demand of the crop resulting from precipitation and irrigation, making it possible to determine the need for irrigation during periods when Peff is not able to supply the crop's water demand.

\section{Water footprint}

Table 4 shows the water footprint of all the crops studied in the municipality of Teofilo Otoni, which are broken down into each of its parameters, the result found was related to the production of family farming in 2017.

Table 4. Water footprint in the family farming sector in the municipality of Teófilo Otoni - MG.

\begin{tabular}{llllll}
\hline Crop & $\begin{array}{l}\text { PHgreen } \\
\left(\mathbf{m}^{3} \cdot \mathbf{t}^{-1}\right)\end{array}$ & $\begin{array}{c}\text { PHblue } \\
\left(\mathbf{m}^{3} \cdot \mathbf{t}^{-\mathbf{1}}\right)\end{array}$ & $\begin{array}{c}\text { PHgray } \\
\left(\mathbf{m}^{3} \cdot \mathbf{t}^{\mathbf{1}}\right)\end{array}$ & $\begin{array}{l}\text { PHtotal } \\
\left(\mathbf{m}^{3} \cdot \mathbf{t}^{-\mathbf{1}}\right)\end{array}$ & $\begin{array}{l}\text { PHTeófilo } \\
\text { Otoni }\left(\mathbf{m}^{\mathbf{3}} \cdot \mathbf{a n o}^{\mathbf{- 1}}\right)\end{array}$ \\
\hline Pumpkin & 360.00 & - & 3.33 & 363.33 & $218,000.00$ \\
Banana & 479.85 & 319.90 & 10.67 & 810.42 & $2,431,250.00$ \\
Chayote & 101.43 & 80.91 & 0.27 & 182.60 & $342,380.35$ \\
Bean & $4,074.67$ & - & 66.67 & $4,141.33$ & $2,981,760.00$ \\
Cassava & 521.60 & - & 10.00 & 531.60 & $5,422,320.00$ \\
Maize & 294.67 & 44.12 & 6.67 & 345.46 & $497,462.40$ \\
Bell pepper & 210.01 & 125.12 & 12.50 & 347.71 & $62,587.90$ \\
Okra & 408.96 & - & 4.17 & 413.13 & $297,451.20$ \\
Cabbage & 156.61 & 122.31 & 4.50 & 283.42 & $283,420.20$ \\
Tangerine & 453.70 & 189.68 & 5.55 & 648.93 & $1,460,103.00$ \\
\hline
\end{tabular}

Source: Authors.

Figure 3 shows the total water footprint of the crops, discriminating among its components: green, blue and gray. It is noted that the cultivation of beans demands greater water volume, being mostly constituted by the green water footprint. The other crops have the same water footprint values, with the green water footprint being the most relevant component. The total water footprint of beans is considered high mainly due to its low productivity, that according to Carvalho et al. (2013) in Brazil are due to the use of rudimentary techniques and inadequate technologies in the management of culture. 
Figure 3. Water footprint of crops cultivated by the family farming sector in the municipality of Teófilo Otoni.

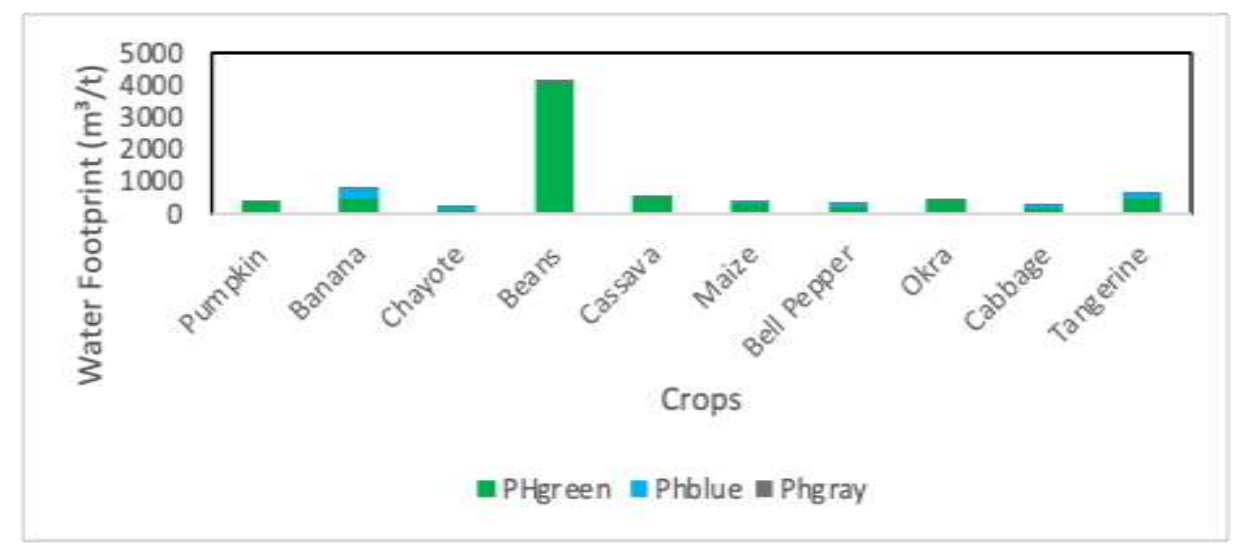

Source: Authors.

The cultivation of pumpkin in the municipality of Teófilo Otoni by family farming obtained a green water footprint of $360 \mathrm{~m}^{3} \cdot \mathrm{t}^{-1}$ and a gray water footprint of $3.33 \mathrm{~m}^{3} \cdot \mathrm{t}^{-1}$ in which nitrogen was a critical nutrient. It is noteworthy that the pumpkin is not a crop sensitive to water deficiency and can be grown without irrigation, for this reason the blue water footprint was not accounted for. In 2017, Teófilo Otoni had a planted area of 50 hectares of pumpkin and a productivity of 12 t.ha ${ }^{-1}$, thus, the municipality's water footprint for the cultivation of pumpkin was $218,000.00 \mathrm{~m}^{3}$. According to studies by Mekonnen \& Hoesktra (2010), which accounted for the global average of some agricultural products through estimated data, obtaining for irrigated pumpkin crops: green water footprint of $228 \mathrm{~m}^{3} \cdot \mathrm{t}^{-1}$, blue water footprint $24 \mathrm{~m}^{3} \cdot \mathrm{t}^{-1}$, gray water footprint of $84 \mathrm{~m}^{3} \cdot \mathrm{t}^{-1}$ reaching a total water footprint of $336 \mathrm{~m}^{3} \cdot \mathrm{t}^{-1}$ that is related to the values found in this study. The discrepancy in relation to the value of the gray water footprint is based on the fact that in the study cited, the application of fertilizers was considered according to a global average, increasing the amount applied of the critical nutrient.

The banana had a green water footprint of $479.85 \mathrm{~m}^{3} \cdot \mathrm{t}^{-1}$, a blue water footprint of $319.90 \mathrm{~m}^{3} \cdot \mathrm{t}^{-1}$ and a gray water footprint of $10.67 \mathrm{~m}^{3} \cdot \mathrm{t}^{-1}$ with phosphorus as the critical nutrient. The total water footprint for banana cultivation by the family farming sector was $810.42 \mathrm{~m}^{3} \cdot \mathrm{t}^{-1}$. The municipality's total water footprint was $2,431,250.00 \mathrm{~m}^{3}$ due to the fact that in 2017 it had a plantation equivalent to 200 hectares with productivity of 15 t.ha ${ }^{-1}$. Clercx et al. (2016) evaluated banana production in Peru and Ecuador, the study observed banana cultivation by small producers obtaining $1,112 \mathrm{~m}^{3} \cdot \mathrm{t}^{-1}$ for production in Ecuador and $1,603 \mathrm{~m}^{3} \cdot \mathrm{t}^{-1}$ for production in Peru. This difference found between the cited values can be justified by the fact that in the study of the mentioned authors, the water needed to clean the packaging for the fruit export process was added in the calculation of the blue water footprint.

The green water footprint obtained in the cultivation of chayote was $101.43 \mathrm{~m}^{3} \cdot \mathrm{t}^{-1}$, the blue water footprint was 80.91 $\mathrm{m}^{3} \cdot \mathrm{t}^{-1}$ and the gray water footprint, related to the carrying of phosphorus, was $0.27 \mathrm{~m}^{3} \cdot \mathrm{t}^{-1}$, producing a total water footprint of $182.60 \mathrm{~m}^{3} \cdot \mathrm{t}^{-1}$. For the production of chayote by the family farming sector, an area of 25 hectares was used with a productivity of $75 \mathrm{t}^{\mathrm{h}} \mathrm{ha}^{-1}$, thus a total water footprint was found for the production of chayote in Teófilo Otoni of $342,380.35 \mathrm{~m}^{3} . \mathrm{t}^{-1}$. According to Mekonnen \& Hoesktra (2010), the average water footprint for the cultivation of chayote in the world is $353 \mathrm{~m}^{3} . \mathrm{t}^{-}$ ${ }^{1}$, which presents the largest contribution of the green water footprint as obtained in this study.

In the cultivation of beans, a water footprint of $4,141.43 \mathrm{~m}^{3} \cdot \mathrm{t}^{-1}$ was observed, being composed of the green water footprint corresponding to $4,074 \mathrm{~m}^{3} \cdot \mathrm{t}^{-1}$ and the gray water footprint generated by the application of phosphorus corresponding to $66.67 \mathrm{~m}^{3} \cdot \mathrm{t}^{-1}$. The area planted for the cultivation of beans in 2017 is equivalent to 800 hectares with a productivity of 0.9 t.ha ${ }^{-1}$, resulting in a total water footprint for the municipality of 2,981,760.00 $\mathrm{m}^{3} . \mathrm{t}^{-1}$. In studies by Soares \& Campos (2013), they obtained the value of $5,690 \mathrm{~m}^{3} \cdot \mathrm{t}^{-1}$ for green water footprint in the cultivation of beans under rainfed conditions in the 
Forquilha watershed in the state of Ceará, the authors observed that the cultivation of beans demanded a greater volume of water compared to another Crop in the region.

The water footprint of the cassava culture, being a dry crop, accounted for only the green water footprint and the gray water footprint, thus obtaining a value of $521.60 \mathrm{~m}^{3} \cdot \mathrm{t}^{-1}$ and $10 \mathrm{~m}^{3} \cdot \mathrm{t}^{-1}$ respectively, generating a water footprint. total of 531.60 $\mathrm{m}^{3} \cdot \mathrm{t}^{-1}$. The nutrient with the greatest impact on the cultivation of cassava was phosphorus. According to the 2017 harvest report, the municipality of Teófilo Otoni obtained a planted area of 850 hectares of cassava with a productivity of 12 t.ha $^{-1}$, thus the water footprint for cassava for the municipality was 5,422,320.00 $\mathrm{m}^{3}$. In an analysis made by Namchancharoen et al. (2015) on irrigated cassava cultivation for the Thailand region, obtained for the green water footprint $415.70 \mathrm{~m}^{3} . \mathrm{t}^{-1}$, for the green water footprint $183.80 \mathrm{~m}^{3} . \mathrm{t}^{-1}$ and did not evaluate the gray water footprint. The total water footprint was $599.50 \mathrm{~m}^{3} \cdot \mathrm{t}^{-1}$, which is consistent with the value obtained for the city of Teófilo Otoni. Another study that corroborates with the results obtained was that of Pires (2018), in which he investigated the dryland cultivation of cassava in the municipality of Tupã - SP, for the green water footprint found the result of $513.70 \mathrm{~m}^{3} \cdot \mathrm{t}^{-1}$ and the water footprint $0.36 \mathrm{~m}^{3} \cdot \mathrm{t}^{-1}$ ash, finding a total water footprint of $514.06 \mathrm{~m}^{3} \cdot \mathrm{t}^{-1}$. The total water footprint of $345.46 \mathrm{~m}^{3} \cdot \mathrm{t}^{-1}$ was obtained for the cultivation of maize, comprising the green water footprint $\left(294.67 \mathrm{~m}^{3} . \mathrm{t}^{-1}\right)$, the blue water footprint $\left(44.12 \mathrm{~m}^{3} \cdot \mathrm{t}^{-1}\right)$ and the footprint gray water $\left(6.67 \mathrm{~m}^{3} \cdot \mathrm{t}^{-1}\right)$ that had phosphorus as a critical nutrient. Family farming in the municipality cultivated 120 hectares of maize in 2017 with a productivity of 12 t.ha $^{-1}$ generating a total water footprint for the municipality of 497,462.40 $\mathrm{m}^{3} \cdot \mathrm{t}^{-1}$. According to Mekonnen and Hoekstra (2010) the global average for maize was $700 \mathrm{~m}^{3} . \mathrm{t}^{-1}$, with approximately double that found in this study, with the green water footprint being the largest contribution with around $65 \%$ of the total water footprint of maize cultivation in the world.

For the production of bell pepper in the municipality, $210 \mathrm{~m}^{3} \cdot \mathrm{t}^{-1}$ was obtained for the green water footprint, 125.12 $\mathrm{m}^{3} \cdot \mathrm{t}^{-1}$ for the blue water footprint and $12.50 \mathrm{~m}^{3} \cdot \mathrm{t}^{-1}$ for the gray water footprint with phosphorus as a critical nutrient , these parameters provided a total water footprint of $347.71 \mathrm{~m}^{3} \cdot \mathrm{t}^{-1}$. The area planted in the municipality was 10 hectares with a productivity of 18 tha $^{-1}$ which produced a total water footprint for the cultivation of bell pepper in Teófilo Otoni of 62,587.90 $\mathrm{m}^{3} \cdot \mathrm{t}^{-1}$. In an analysis made by Mekonnen \& Hoesktra (2011) for the production of bell pepper in Australia, they obtained the total water footprint of $472 \mathrm{~m}^{3} \cdot \mathrm{t}^{-1}$, which is close to the value found in the municipality of Teófilo Otoni.

Okra had a total water footprint of $413.13 \mathrm{~m}^{3} \cdot \mathrm{t}^{-1}$, as it is a dryland crop, the production of this crop has only the green water footprint $\left(408.96 \mathrm{~m}^{3} \cdot \mathrm{t}^{-1}\right)$ and the gray water footprint $\left(4,17 \mathrm{~m}^{3} \cdot \mathrm{t}^{-1}\right)$ generated by nitrogen leaching. The municipality's total water footprint for the cultivation of okra was $297,451.20 \mathrm{~m}^{3} \cdot \mathrm{t}^{-1}$, due to the planted area of 60 hectares with productivity

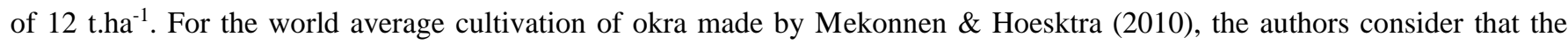
cultivation is done under irrigated conditions and values for the green water footprint of $474 \mathrm{~m}^{3} \cdot \mathrm{t}^{-1}$ were found, blue water footprint $36 \mathrm{~m}^{3} \cdot \mathrm{t}^{-1}$ and the gray water footprint of $65 \mathrm{~m}^{3} \cdot \mathrm{t}^{-1}$, thus obtaining a total water footprint of $576 \mathrm{~m}^{3} \cdot \mathrm{t}^{-1}$. The disparity in the values found with this study can be motivated by the difference between cultivation conditions considered.

The total water footprint of cabbage cultivation was $283.42 \mathrm{~m}^{3} \cdot \mathrm{t}^{-1}$, being cultivated under irrigated conditions it presented a green water footprint of $156.61 \mathrm{~m}^{3} \cdot \mathrm{t}^{-1}$, blue water footprint of $122.31 \mathrm{~m}^{3} \cdot \mathrm{t}^{-1}$ and footprint gray water of $4.50 \mathrm{~m}^{3} \cdot \mathrm{t}^{-1}$ with nitrogen as a critical nutrient. With a planted area of 25 hectares and a production of 25 t.ha $^{-1}$, The values found are confirmed by Nyambo \& Wakindiki (2015), who, in the analysis of vegetable cultivation by small producers in South Africa, found a total water footprint of $254.50 \mathrm{~m}^{3} \cdot \mathrm{t}^{-1}$ for the production of cabbage, composed of the footprint green water of 138.30 $\mathrm{m}^{3} \cdot \mathrm{t}^{-1}$, blue water footprint of $79.20 \mathrm{~m}^{3} \cdot \mathrm{t}^{-1}$ and the gray footprint of $37 \mathrm{~m}^{3} \cdot \mathrm{t}^{-1}$ the municipality had a total water footprint of $283,420.20 \mathrm{~m}^{3} \cdot \mathrm{t}^{-1}$.

The tangerine had a green water footprint of $453.70 \mathrm{~m}^{3} \cdot \mathrm{t}^{-1}$, a blue water footprint of $189.68 \mathrm{~m}^{3} \cdot \mathrm{t}^{-1}$ and a gray water footprint of $5.55 \mathrm{~m}^{3} . \mathrm{t}^{-1}$ for the carrying of phosphorus, generating a water footprint. total of $648.93 \mathrm{~m}^{3} \cdot \mathrm{t}^{-1}$. For the cultivation of 
tangerine in 2017 in the municipality of Teófilo Otoni, an area of 150 hectares was required with a productivity of 15 t.ha ${ }^{-1}$. According to Seixas (2011) the production of oranges in Portugal demands a water footprint of $556 \mathrm{~m}^{3} \cdot \mathrm{t}^{-1}$.

Crops produced exclusively by the family farming sector in the municipality of Teófilo Otoni in 2017 required $13,996,735.05 \mathrm{~m}^{3} \cdot \mathrm{t}^{-1}$. The green water footprint has the greatest influence, as it constitutes $86 \%$ of the total water footprint, the blue water footprint represents $12.5 \%$ and the gray water footprint is equivalent to $1.5 \%$ of the total water footprint for family farming. High values of the green water footprint were also observed in the works of Lacerda (2015), Costa et al. (2016) and Pinto \& Barbosa (2017). However, in studies by Lira et al. (2014) in the agricultural sector in Chile, found a blue water footprint with greater representativeness than the other components of the total water footprint, thus the authors concluded that this fact can be explained due to the fact that the studied region has low average rainfall.

\section{Economic water productivity}

The amount of water used to generate each $\mathrm{R} \$ 1.00$ for each kilo crop is shown in Table 5. The crop with the highest economic water productivity is chayote $\left(64.451 . R \$^{-1}\right)$ and the crop with the lowest economic water productivity is beans (530.94 1.R $\${ }^{-1}$ ). The family farming sector of Teófilo Otoni demands an average of 196.73 liters for a production of R $\$ 1.00$.

Table 5. Economic water productivity for crops produced exclusively by family farming in the municipality of Teófilo Otoni.

\begin{tabular}{ll}
\hline Crop & Liters.R $^{\mathbf{1}}$ \\
\hline Pumpkin & 150.34 \\
Banana & 374.04 \\
chayote & 64.45 \\
Bean & 530.94 \\
Cassava & 205.78 \\
Maize & 95.96 \\
Bell pepper & 99.35 \\
Okra & 127.12 \\
Cabbage & 103.06 \\
Tangerine & 216.31 \\
\hline
\end{tabular}

Source: Authors.

According to Soares and Campos (2013), the average economic water productivity for the bean crop was 5,480 1.R $\$^{-1}$ in a year of normal precipitation for the semiarid region of Brazil, since as mentioned above the total water footprint for the bean cultivation in the region was higher than the obtained value. The authors accounted for the economic productivity of water for other crops, obtaining an average value of $2,2201 . R \$^{-1}$.

The economic productivity of water is strongly related to the yield of the crops, so to reduce the water footprint and improve the generation of income per liter of water incorporated in the production, it is necessary to improve the productivity of the crops. Therefore, in order to achieve better yields, it is essential to apply good agricultural practices, especially for small producers who deal with scarce environmental resources. (GHEEWALA, et al., 2014).

\section{Final Considerations}

With this study it was proposed to evaluate the water footprint and the economic productivity of water for crops produced exclusively by the family farming sector in the city of Teófilo Otoni. 
The water footprint methodology proved to be effective for determining the volume of water incorporated in all stages of the production process of the family farming sector in Teófilo Otoni, with the total water footprint for the year 2017 being $13,996,735.05 \mathrm{~m}^{3} \cdot \mathrm{t}^{-1}$. Where the green water footprint represents $86 \%$ of the total water footprint, the blue water footprint represents $12.5 \%$ and the gray water footprint equals $1.5 \%$. The calculation of the water footprint indicated that families are dependent on the water inserted in the green water footprint parameter for agricultural and income production.

Of the crops produced exclusively by family farmers, the cultivation of beans had the largest water footprint and the cultivation of chayote had the smallest water footprint, consequently, these results interfered in the economic water productivity for the sector, the greater the water footprint the lower the economic productivity of water for the crop.

As the study was a pioneer in relation to the use of this Water Footprint methodology in family farming, it is expected to be an incentive for greater concern in the management of water resources. In this way, some possible future works may complement the present study, such as: evaluation of the water footprint in the inputs used in each crop, expansion of the database providing greater reliability, performing the water footprint in irrigated crops, among others.

\section{References}

Almeida, R. A. (2016) Modelagem hidrológica na bacia do rio Mucuri com a utilização do modelo SWAT. 2016. 112p. Tese (Doutorado em Engenharia Agrícola) - Departamento de Engenharia Agrícola, Universidade Federal de Viçosa, Viçosa.

Almeida, R. F. B., Ferreira Junior, L. G. \& Bayer, M. (2018). Análise da cobertura e uso da terra da bacia hidrográfica do rio do Coco e suas implicações sobre as áreas de preservação permanente como instrumento na gestão dos recursos hídricos. Desenvolvimento e Meio Ambiente 49 , $60-82$. doi: $0.5380 /$ dma.v49i0.58652.

Carvalho, I. R., Korcelski, C., Pelissari, G., Hanus, A. D. \& Rosa, G. M. (2013). Demanda hídrica das culturas de interesse agronômico. Enciclopédia Biosfera, 9 (17).

Carvalho, D. F., Rocha, H. S., Bonomo, R.\& Souza, A. P. (2015). Estimativa da evapotranspiração de referência a partir de dados meteorológicos limitados. Pesquisa Agropecuária Brasileira, 50(1), 1-11.

Clercx L., Torres, E. Z. \& Kuiper, J. D. (2016). Water footprint assessment of bananas produced by small banana farmers in Peru and Ecuador. Acta Horticulturae, 5, 1-8.

Companhia energética de minas gerias, CEMIG (2012). Atlas Solarimétrico de Minas Gerais, 1ed. Belo Horizonte.

Conama - Conselho Nacional do Meio Ambiente (2005). Resolução nº 357, de 17 de março de 2005. Brasília: DOU de 18/3/2005.

Costa, D. C., Martorano, L. G., Marques, M. C., El-husny, J. C. \& Nacif, A. (2016). Pegada hídrica como indicador de sustentabilidade em polo de grãos na Amazônia. Enciclopédia Biosfera, 13(23), 920-929.

Empresa brasileira de assistência técnica e extensão RURAL - EMATER (1982). Sistema de produção para a cultura do quiabo. 1ed. Belo Horizonte.

Empresa brasileira de pesquisa agropecuária - EMBRAPA (1994). Cultivo de repolho (Brassica oleracea var. Capitata) no Acre. 1ed. Acre.

Empresa brasileira de pesquisa agropecuária - EMBRAPA (2002). Manejo e tratos culturais para o cultivo do milho verde. 1ed. Sete Lagoas

Empresa brasileira de pesquisa agropecuária - EMBRAPA (2003). Sistema de Produção. 1ed. Brasília.

Empresa brasileira de pesquisa agropecuária - EMBRAPA (2006). Banana: Instruções prática de cultivo. 1ed. Cruz das Almas.

Empresa brasileira de presquisa agropecuária - EMBRAPA (2010). Aspectos técnicos do cultivo da abóbora na região nordeste do Brasil. 1ed. Aracaju.

Empresa brasileira de pesquisa agropecuária - EMBRAPA (2012). Irrigação na cultura do pimentão. 1ed. Brasília.

Empresa brasileira de pesquisa agropecuária - EMBRAPA (2013). O feijão-comum no Brasil passado, presente e futuro. 1ed. Santo Antônio de Goiás.

Empresa brasileira de pesquisa agropecuária - EMBRAPA (2015). Irrigação na cultura do chuchu. 1ed. Brasília.

Fao, food and agriculture organization of the united nations (2018). CROPWAT 8.0 model, FAO, Rome. www.fao.org/nr/water/infores_ databases_cropwat.html.

Fundação nacional de saúde - FUNASA (2014). Manual de controle de qualidade da água para técnicos que trabalham em ETA. http://www.funasa.gov.br/biblioteca-eletronica/publicacoes/saude-ambiental/-/asset_publisher/G0cYh3ZvWCm9/content/manual-de-controle-da-qualidade-daagua-para-tecnicos-que-trabalham-em-etas?inheritRedirect=false.

Godinho, A. L. F., Marangon, B., Ribeiro, I. C., Fernandez, M. A., Gonçalves, B. B. \& Freitas, P. M. C. (2008). Proposta de Criação do Comitê de Bacia Hidrográfica dos Afluentes Mineiros do Mucuri MU1. 
Gheewala, S. H., Silaletruksa, T., Nilsalab, P., Mungkung, R., Perret, S. R. \& Chaiyawannakaru, N. (2014). Water footprint and impact of water consumption for food, feed, fuel crops production in Thailand. Water, 6, $1698-1718$. doi:10.3390/w6061698.

Hoekstra, A. Y., Chapagain, A. K., Aladaya, M. M. \& Mekonnen, M. M. (2011). Manual de avaliação de pegada hídrica: estabelecendo o padrão global. 1 ed. Earthscan. https://www.waterfootprint.org/media/downloads/ManualDeAvaliacaoDaPegadaHidrica.pdf

Hoekstra, A. Y. \& Mekonnen, M.M. (2019). The green, blue and gray water footprint of crops and derived crop products. UNESCO. https://waterfootprint.org/media/downloads/Report47-WaterFootprintCrops-Vol1.pdf.

Instituto brasileiro de geografia e ESTÁTISTICA - IBGE (2016). Teófilo Otoni. http://cod.ibge.gov.br/3UT.

Instituto nacional de meteriologia - INMET (2018). Estações meteorológicas automáticas. https://portal.inmet.gov.br/

Kottek, M. et al. (2006) World map of the Köppen - Geiser climate classification updated. Meteorologische Zeitschrift, 15(3), 259 - 263.

Lacerda, P. P. (2015). Pegada hídrica na bacia do ribeirão Pipirapau: uma nova abordagem metodológica. 2015. 37p. Trabalho de conclusão de curso (Especialização em Engenharia Florestal) - Faculdade de Tecnologia, Universidade de Brasília, Brasília.

Lira, J., Donoso, G., Blanco, E. \& Franco, G. (2014). An estimation of agriculture water footprint in Chile. Research Gate. $5(2), 259$ - 263.

Mccoy, R. M. (2005). Fields's methods in remote sensing. New York: The Guilford Press.

http://www2.fct.unesp.br/docentes/carto/enner/PPGCC/Comportamento\%20Espectral\%20de\%20Alvos/Livros/Field_Methods_in_Remote_Sensing.pdf

Ministério da agricultura, pecuária e abastecimento - MAPA (2016). Produção de carne no Brasil aumenta $45 \%$ em 15 anos: no mesmo período o rebanho cresceu 25\%. http://www.agricultura.gov.br/comunicacao/noticias/2016/04/producao-de-carne-no-brasil-aumenta-45porcento-em-15-anos.

Namchancharoen, T., Papong, S., Malakul, P. \& Mungcharoen, T. (2015) The carbon and water footprint assessment of cassava-based bioethanol production in Thailand. In: International conference on biological envorinment and food engineering, Singapura. Anais... Singapura.

Nascimento, T. V. \& Fernandes, L. L. (2017). Mapeamento de uso e ocupação do solo em uma pequena bacia hidrográfica da Amazônia. Ciência e Natura, 39(1), 179-178.

Nogueira, A. C. V. O. (2010). Água, um recurso natural indispensável à vida. 2010. 49p. Monografia (Especialização em Educação Ambiental) - Universidade Cândido Sales, Divinópolis de Goiás.

Nyambo, P. \& Wakindiki, I. I. C. (2015). Water footprint of growing vegetables in selected smallholder irrigation schemes in South Africa. Water SA, 41(4).

Organizações das nações unidas - ONU (2015). Water for sustainable world. UNESCO. http://www.unesco.org/new/en/naturalsciences/environment/water/wwap/wwdr/2015-water-for-a-sustainable-world/.

Palhares, J. C. P. (2011). Pegada hídrica dos suínos abatidos nos estados da região centro-sul do Brasil. Animal Science, $33(3)$, 309 - 314. doi:10.4025/actascianimsci.v33i3.9924

Pinto, D. B. F. \& Barbosa, A. L. G. (2019). Uma abordagem da pegada hídrica no setor pecuário de Teófilo Otoni - MG. Revista Vozes dos Vales,11(6), 1- 16. http://site.ufvjm.edu.br/revistamultidisciplinar/files/2017/03/Daniel2302.pdf.

Piovesan, R. P. (2006). Perdas de nutrientes via superfície em colunas de solo sob adubação mineral e orgânica. 2006. 73p. Dissertação (Mestrado em Agronomia) - Universidade Federal do Paraná, Curitiba, Paraná.

Pires, L. F. (2018). Pegada hídrica como instrumento de gestão dos recursos hídricos: Análise em fecularias dos escritórios de desenvolvimento rural de Assis. 111p. Dissertação (Mestrado em Agronegócio e Desenvolvimento) - Universidade Estadual Paulista, Tupã.

Seixas, V. S. C. (2011). Análise da pegada hídrica de um conjunto de produtos agrícolas. 89p. Tese (Mestrado em Engenharia Ambiental) - Faculdade de Ciência e Tecnologia, Universidade Nova de Lisboa, Lisboa.

Silva, M. S., Bueno, I. T., Acerbi junior, F. W., Borges, L. A. C. \& Calegario, N. (2017). Avaliação da cobertura do solo como indicador de gestão de recursos hídricos: um caso de estudo na sub-bacia do Córrego dos Bois, Minas Gerais. Engenharia Sanitária Ambiental, 22(3).

Soares, R. B. \& Campos, K.C. (2013). Uso e disponibilidade hídrica no Brasil. Revista de Política Agrícola, $22(3), 48$ - 57.

USDA, United states department of agriculture (1994). 'The major world crop areas and climatic profiles', Agricultural Handbook, n. 664, World Agricultural Outlook Board, USDA. 